Original Research Paper

\title{
Optimalisasi Minat Belajar dengan Metode Fun Learning pada Era New Normal di Desa Sengkerang, Kecamatan Praya Timur
}

\author{
Ahmad Azmi Alwahidi', M. Irwan Sani' ${ }^{2}$, Aluh Mustika Dewi ${ }^{3}$, Sofihara Seli Darmawangsa ${ }^{3}$, Titi Nur \\ Alawiyah $^{3}$, Siti Rohimah ${ }^{4}$, Zahratul Imtihan ${ }^{5}$, Widia Hasmiati ${ }^{6}$, Hidayatul Mustapida ${ }^{6}$, Kurniasih \\ Sukenti $^{6}$
}

${ }^{I}$ Program Studi Teknik Informatika, Fakultas Teknik, Universitas Mataram, Mataram, Indonesia;

${ }^{2}$ Program Studi Agroekotekonologi, Fakultas Pertanian, Universitas Mataram, Mataram, Indonesia;

${ }^{3}$ Program Studi Pendidikan Matematika, FKIP, Universitas Mataram, Mataram, Indonesia;

${ }^{4}$ Program Studi Pendidikan Biologi, FKIP, Universitas Mataram, Mataram, Indonesia;

${ }^{5}$ Program Studi Ilmu Hukum, Fakultas Hukum, Universitas Mataram, Mataram, Indonesia;

${ }^{6}$ Program Studi Biologi, FMIPA, Universitas Mataram, Mataram, Indonesia

DOI: https://doi.org/10.29303/jpmpi.v4i2.682

Sitasi: Alwahidi, A. A., Sani, M. I., Dewi, A. M., Darmawangsah, S. S., Alawiyah, T. N., Rohimah, S., Imtihan, Z., Hasmiati, W., Mustapida, H., \& Sukenti, K. (2021). Optimalisasi Minat Belajar dengan Metode Fun Learning pada Era New Normal di Desa Sengkerang, Kecamatan Praya Timur. Jurnal Pengabdian Magister Pendidikan IPA, 4(2)

Article history

Received: 03 Februari 2021

Revised: 08 Maret 2021

Accepted: 10 April 2021

*Corresponding Author: Ahmad Azmi Alwahidi, Program Studi Teknik Informatika, Fakultas Teknik, Universitas Mataram, Mataram, Indonesia;

Email:

kknprayatimur@gmail.com

\begin{abstract}
Fun learning merupakan strategi dalam mengajar dimana suasana dalam mengajar dikondisikan nyaman sehingga siswa dapat berkonsentrasi penuh pada proses pembelajaran. Fun learning dipilih sebagai metode belajar karena selama masa pandemi Covid-19 ini minat belajar anak-anak cendrung menurun sehingga diperlukan upaya untuk mengoptimalisasi minat belajar anak. Tujuan kegiatan ini adalah untuk memperkenalkan strategi belaja Fun Learning pada anak-anak TK dan SD/MI di Desa Sengkerang, Kecamatan Praya Timur, Kabupaten Lombok Tengah, untuk membantu mengatasi kesulitan belajar selama era pandemi Covid-19. Hal ini terkait dengan tema Kuliah Kerja Nyata (KKN) saat ini yaitu Mengajar di Desa, untuk membantu anak-anak dalam hal belajar, dalam bentuk kegiatan bimbingan belajar. Kegiatan bimbingan belajar dapat membantu memotivasi semangat belajar anak-anak selama masa pandemi dimana berbagai kegiatan belajar -mengajar memiliki banyak keterbatasan.. Beberapa pelajaran yang diberikan adalah Bahasa Inggris, IPA, Matematika, dan Agama. Kegiatan ini diharapkan dapat membentuk anak menjadi pribadi yang semakin termotivasi untuk belajar sehingga dapat meningkatkan pengetahuan dan wawasan anak-anak.
\end{abstract}

Keywords: Fun learning, pandemi, belajar

\section{Pendahuluan}

Pendidikan merupakan suatu proses yang diperlukan untuk mendapatkan keseimbangan dan kesempurnaan dalam pengembangan individu maupun masyarakat. Pendidikan juga merupakan sebuah aktifitas yang memiliki maksud atau tujuan tertentu yang diarahkan untuk mengembangkan potensi yang dimiliki manusia baik sebagai manusia ataupun sebagai masyarakat dengan sepenuhnya (Nurkholis, N.). Keberhasilan kegiatan belajar dan pembelajaran, seslain dipengaruhi oleh faktor guru juga dipengaruhi oleh faktor siswa itu sendiri. Tingkah laku siswa ketika mengikuti proses pembelajaran dapat mengindikasikan akan 
ketertarikan siswa tersebut terhadap pembelajaran tu stau sebaliknya,ia merasa tidak tertaarik dengan pembelajaran tersebut. Ketertarikan siswa inilah yang sering dikenal dengan istilah minat. Mengingat pentingnya minat dalam belajar, Ovide Declory yang dikutip oleh Moh. Uzer Usman (2001), mendasarkan sistem pendidikannya pada pusat minat yang ada pada umumnya yang dimiliki pada setiap orang sehingga pada hakikatnya setiap ada berminat terhadap belajar, dan guru sendiri hendaknya berusaha membangkitkan minat anak dalam belajar. Adanya perubahan kebiasaan belajar akibat pandemi membuat minat belajar anak berkurang. Sehingga diperlukan bimbingan dan metode pembelajaran yang menarik minat kembali anak-anak untuk belajar, salah satunya dengan menggunakan metode fun learning.

Fun learning merupakan strategi dalam mengajar yang suasana dalam mengajar nyaman sehingga siswa dapat berkonsentrasi penuh pada pembelajaran (Asmani, J.M. 2014). Konsep fun learning bukan menciptakan suasana belajar yang menyenangkan namun tak terkontrol. Namun fun learning mengarah pada suasana pembelajaran yang diciptakan melalui disain pembelajaran yang terencana. Adapun karakteristiknya yakni, dalam proses pembelajaran akan muncul minat dan motivasi yang tinggi dalam belajar. Selain itu dalam penerapannya suasana mengajar akan dibuat senyaman mungkin untuk pembelajaran sehingga proses pembelajaran lebih aktif, kreatif, efektif, dan menyenangkan. Sehingga dengan menggunakan strategi fun learning diharapkan dapat meningkatkan minat dan semangat belajar siswa yang kurang karena kesusahan dalam belajar di era pandemai. Dampaknya siswa dapat lebih paham dalam belajar.

New normal adalah sebuah perubahan budaya hidup yang dicanangkan pemerintah Republik Indonesia agar masyarakat dapat terbiasa dengan tatanan hidup normal yang baru untuk menghadapi penyebaran virus Corona. Prinsip new normal adalah bisa menyesuaikan dengan pola hidup. Selain perubahan perilaku masyarakat, new normal juga merubah paradigma ritme kehidupan masyarakat, salah satunya dalam melakukan kegiatan belajar mengajar.
Desa Sengkerang merupakan salah satu desa di Kecamatan Praya Timur, Kabupaten Lombok Tengah. Para orang tua di desa ini juga menghadapi problem yang sama terkait menurunnya minat dan motivasi belajar anak-anak di era pandemi. Oleh sebab itu, perlu dilakukan upaya-upaya untuk mengatasi hal ini agar kegiatan belajar mengajar bagi siswa di Desa Sengkerang dapat terus berjalan lancar dan memperoleh hasil yang optimal. Tujuan kegiatan ini adalah untuk memperkenalkan strategi belaja Fun Learning pada anak-anak TK dan SD/MI di Desa Sengkerang, untuk membantu mengatasi kesulitan belajar selama era pandemi Covid-19.

\section{Metode}

Kegiatan dengan tema program Mengajar di Desa ini dilakukan dalam bentuk bimbingan belajar (Bimbel) dengan sasaran pada 4 mata pelajaran yakni Matematika, IPA, Bahasa Inggris Dasar, dan Pengetahuan Agama. Selain itu, kegiatan ini juga didukung dengan program tambahan berupa Taman Baca yang diadakan di Dusun Pinggir, Mengajar di TPQ, Vertical Garden, pembersihan lingkungan, dan lomba pada penghujung KKN. Metode yang digunakan dalam pelaksanaan mengajar adalah metode fun learning dengan mahasiswa KKN terlibat sebagai guru/pengajar. Peserta didik merupakan anak-anak usia sekolah (TK dan SD/MI) yang tinggal di Desa Sengkerang. Kegiatan ini dilaksanakan di Madrasah Ibtida'iyah Hidayatussibyan NW Sengkerang, Posko, dan Balai Didik Dusun Pinggir, Desa Sengkerang.

\section{Hasil dan Pembahasan}

Kegiatan Mengajar di Desa ini pada dasarnya sejalan dengan tujuan pendidikan di Indonesia secara umumnya, yaitu agar peserta didik dapat mengembangkan potensi dirinya menjadi pribadi yang lebih baik. Dalam UU No.20 tahun 2003 dinyatakan bahwa pendidikan adalah usaha dasar dan terencana untuk mewujudkan suasana belajar dan proses pembelajaran agar peserta didik secara aktif mengembangkan potensi dirinya untuk memiliki kekuatan spiritual keagamaan, pengendalian diri, kepribadian, kecerdasan, akhlak mulia, serta keterampilan, yang diperlukan dirinya, masyarakat, dan Negara (Aas, 2018).

$$
\text { Kegiatan mengajar di desa ini }
$$
dititikberatkan dalam pembelajaran membaca, 
menulis, berhitung (calistung), Matematika, IPA, Bahasa Inggris Dasar, dan Pengetahuan Agama, bagi anak-anak usia TK hingga SD/MI (Gambar 1). Pelaksanaan kegiatan dilakukan di Madrasah Ibtida'iyah Hidayatussibyan NW Sengkerang, Posko, dan juga Balai Didik Dusun Pinggir yang memiliki kegiatan rutin pada Program Santai yang berlokasi di Desa Sengkerang, Kecamatan Praya Timur. Program ini juga didukung dengan kegiatan tambahan yang dilakukan pada hari Jum'at dan Minggu, dengan kegiatan terkait pembelajaran, peningkatan kreativitas, dan kebersihan lingkungan. Program kerja tambahan yang dilakukan selama masa KKN berupa Taman Baca di Program Santai, Vertikal Garden, Kebersihan Lingkungan, dan Lomba pada akhir masa KKN.

Program mengajar ini berjalan dengan baik dan lancar, dan diikuti oleh para peserta didik dengan tingkat antusiasme yang baik. Kendala yang umum dihadapi adalah perbedaan tingkat pendidikan tiap anak dan kurangnya kemandirian maupun kepercayaan diri pada anak-anak. Hal ini menyebabkan anak-anak menjadi terkendala dalam belajar, tidak mandiri ataupun mudah menyerah ketika menemukan kesulitan dan seringkali tidak mengikuti peraturan yang sudah ditetapkan.

Program wajib tema Mengajar di Desa dengan metode fun learning dan dengan dukungan program tambahan memiliki tujuan baik secara jangka pendek maupun panjang (Gambar 2). Untuk jangka pendek, selain sebagai salah satu upaya peningkatan pembelajaran anak di Desa Sengkerang pada era new normal, juga merupakan upaya untuk meningkatkan motivasi belajar anak dan membantu anak dalam mempelajari pelajaran di sekolah yang tidak bisa mereka dapatkan secara keseluruhan akibat terganggunya proses belajar-mengajar akibat pandemi Covid-19. Hal lain yang didapatkan adalah adanya peningkatan kreativitas dan kesadaran masyarakat akan kebersihan lingkungan. Sementara itu, secara jangka panjang kegiatan ini dapat menanamkan kebiasaan dan pola belajar yang baik, serta semangat belajar anak dalam kehidupan seharihari dalam kondisi apapun. Menurut Purwanto (1990), belajar adalah merupakan suatu perubahan yang terjadi melalui latihan dan pengalaman, dalam arti perubahan-perubahan yang disebabkan oleh pertumbuhan atau kematangann tidak dianggap sebagai belajar, seperti perubahan-perubahan yang terjadi pada seorang bayi. Sudjana (1996) menyatakan bahwa belajar bukan menghapal dan bukan pula mengingat, belajar merupakan suatu proses yang ditandai denga adanya perubahan pada diri seseorang. Belajar juga merupakan suatu proses usaha yang dilakukan seseorang untuk memperoleh suatu tingkah laku baru secara keseluruhan, sebagai hasil pengalaman sendiri dalam interaksi dalam lingkungannya (Slameto, 1996)

Metode fun learning merupakan strategi dalam mengajar dimana suasana dalam mengajar dan belajar dikondisikan agar nyaman sehingga siswa dapat berkonsentrasi penuh pada pembelajaran (Asmani, 2014). Konsep fun learning bukan menciptakan suasana belajar yang menyenangkan namun tak terkontrol, namun fun learning mengarah pada suasana pembelajaran yang diciptakan melalui desain pembelajaran yang terencana. Adapun karakteristiknya yakni, dalam proses pembelajaran akan muncul minat dan motivasi yang tinggi dalam belajar. Selain itu dalam penerapannya suasana mengajar akan dibuat senyaman mungkin untuk pembelajaran sehingga proses pembelajaran lebih aktif, kreatif, efektif, dan menyenangkan. Pembelajaran fun learning adalah strategi yang digunakan untuk menciptakan lingkungan belajar yang efektif, menerapkan kurikulum, menyampaikan materi, memudahkan proses belajar yang mengakibatkan prestasi belajar peserta didik mengalami peningkatan (Darmasyah, 2011).

Beberapa bentuk pengkondisian suasana belajar yang nyaman adalah dengan pemberian ice breaking pada saat pembelajaran. Ice breaking merupakan kegiatan untuk memecah kebuntuan atau mencairkan suasana, yang dapat berupa kegiatan bernyanyi, bermain, bercerita, dan lainnya. Kegiatan ini bahkan bisa juga didukung dengan membuat sumber belajar kreatif seperti komik untuk membuat siswa lebih terarik dalam belajar. Dengan kegiatan belajar menggunakan strategi fun learning ini diharapkan dapat meningkatkan minat dan semangat belajar siswa yang kurang atau rendah karena kesulitan dalam belajar di era pandeai. Dampak positif yang ditimbulkan siswa dapat lebih paham dalam mempelajari materi yang diberikan, sehingga termotivasi terus untuk belajar. 


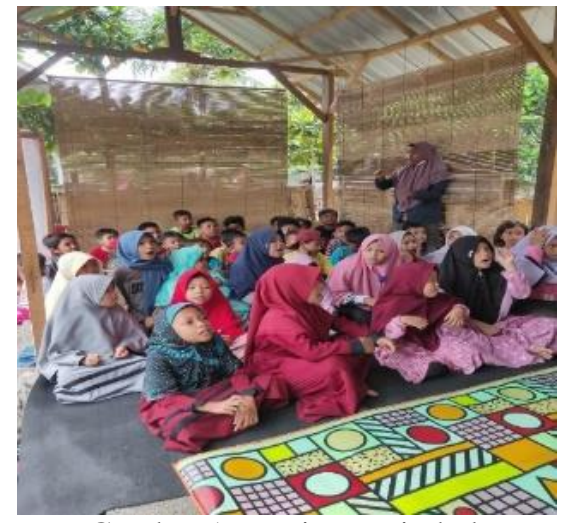

Gambar 1. Kegiatan Bimbel

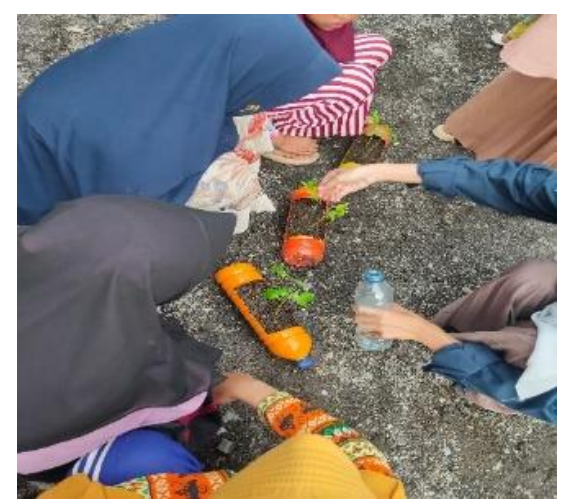

Gambar 2. Fun Learning

Dari hasil kegiatan peserta didik memberikan respon yang baik terhadap penerapan strategi Fun Learning. Hal ini tampak dari antusiasme dan semangat para peserta dalam mengikuti setiap kegiatan, dan selalu menyambut baik setiap arahan dan upaya para pengajar dalam menerapkan berbagai kegiatan Fun Learning pada tiap pertemuan. Peserta didik mengaku lebih menyukai metoda belajar ini karena merasa lebih bisa memahami materi yang diberikan karena rasa jenuh dan bosan dapat teratasi dengan adanya strategi ice breaking pada tiap kegiatan. Para orang tua siswa juga menyambut baik hasil kegiatan ini, terbukti dari komunikasi yang disampaikan bahwa anak-anak mereka lebih menikmati kegiatan belajar dibandingkan saat sebelum diperkenalkannya metode Fun Learning. Diharapkan bahwa metode ini dapat terus diterapkan dalam tiap kegiatan belajar anak-anak TK-SD/MI di Desa Sengkerang.

\section{Kesimpulan}

Metode Fun Learning dapat digunakan sebagai alternatif strategi belajar untuk mengatasi kurangnya minat belajar pada anak-anak TK-SD/MI di Desa Sengkerang. Metode ini memiliki dampak jangka pendek dan jangka panjang yang baik jika diterapkan dengan intensif terutama selama masa pandemi, untuk dapat menjaga motivasi dan semangat belajar siswa.

\section{Saran}

Pada kegiatan selanjutnya diharapkan penerapan strategi Fun Learning dapat pula diperkenalkan pada lokasi atau desa lain agar lebih banyak lagi anakanak yang dapat merasakan manfaatnya. Orang tua agar dituntut lebih berpartisipasi aktif dalam mencermati strategi ini untuk dapat menerapkannya di rumah masing-masing selama masa pandemi.

\section{Ucapan Terima Kasih}

Ucapan terima kasih disampaikan kepada civitas akademika Universitas Mataram dan seluruh perangkat desa serta warga Desa Sengkerang, Kecamatan Praya Timur, yang telah membantu pelaksanaan kegiatan ini.

\section{Daftar Pustaka}

Aas, S. S. 2018. Teori-teori Pendidikan dalam Al Qur'an. Jurnal Pendidikan Islam. Vol 07, No. 1

Asmani, J.M. 2014. 7 Tips Aplikasi PAKEM ( Pembelajaran Aktif, Kreatif, Efektif, dan Menyenangakan). Jogjakarta: DIVAPress.

Darmasyah. 2011. Strategi Pembelajaran Menyenangkan dengan Humor. Jakarta: Bumi Aksara.

Nurkholis, N. 2013. Pendidikan dalam Upaya Memajukan Teknologi. Jurnal Kependidikan 1(1), 24-44.

Purwanto, 1990. Pisikologi Pendidikan. Bandung: PT Remaja Rasdakarya.

Slameto. 1991. Proses Belajar Mengajar dalam Sistem Kredit Semester. Jakarta: Rineka Cipta.

Sudjana, N. 1996. Cara Belajar Siswa Aktif Dalam Proses Mengajar. Bandung: Sinar Baru Algensindo.

Usman, Uzer, M. \& Lilis, S. 2001. Upaya Optimalisasi Kegiatan Belajar Mengajar. Bandung: Remaja Rosdakarya. 